www.jmscr.igmpublication.org

Impact Factor (SJIF): 6.379

Index Copernicus Value: 79.54

ISSN (e)-2347-176x ISSN (p) 2455-0450

crossrefDOI: https://dx.doi.org/10.18535/jmscr/v7i1.52

\title{
An Unusual Presentation of Sickled Cell Anemia with Splenomegaly -A Case Report
}

Authors

\section{Dr K.Shalini (PG), Dr K.Ambedkar Raj MD Professor, Dr V. Sarada Professor \&HOD \\ Trichy Srm Medical College and Research Centre}

\section{Introduction}

Sickle cell anemia is very common single gene disorder. $50 \%$ of world population affected by sickle cell anemia resides in India. The average frequency of sickle cell gene ranges between 22$44 \%$. High prevalence has been found in various tribal community of India. Splenomegaly usually evident at six months of age but undergoes autosplenectomy by 8 years of age.

\section{Clinical History}

A 11 year old girl presented with history of high coloured urine, yellowish discolouration of sclera, fatigability, failure to thrive since 2 years .Also complained of abdomen distension with mild pain and intermittent low grade fever since 6 months.

\section{Examination}

On Examination - Pallor +, Icterus +, Hemolytic faces +

CVS -S1S2+, RS -BAE +

P/A -Soft, Splenomegaly INVESTIGATION:

\section{Complete Hemogram}

Hb-3.5g/dl, RBC- 1.23millions/ml, PCV - 12\%, MCV- 97.6 fl, MCH - 28.9pg,
MCHC -29.6g/dl. WBC-5420cells/cmm, Platelet 41000cells/microlitre

\section{Peripheral Smear Study}

RBC - Predominantly Microcytic Hypochromic red cells with moderate anisopoikilocytosis. Sickle cells, target cells and nucleated RBCs seen. Occasional macrocytes and polychromatophils seen.

WBC- Normal in number, morphology and distribution.

Platelet- Reduced in count. Giant platelets seen.

Impression-

1. Hemolytic Anemia.

2.Thrombocytopenia. 

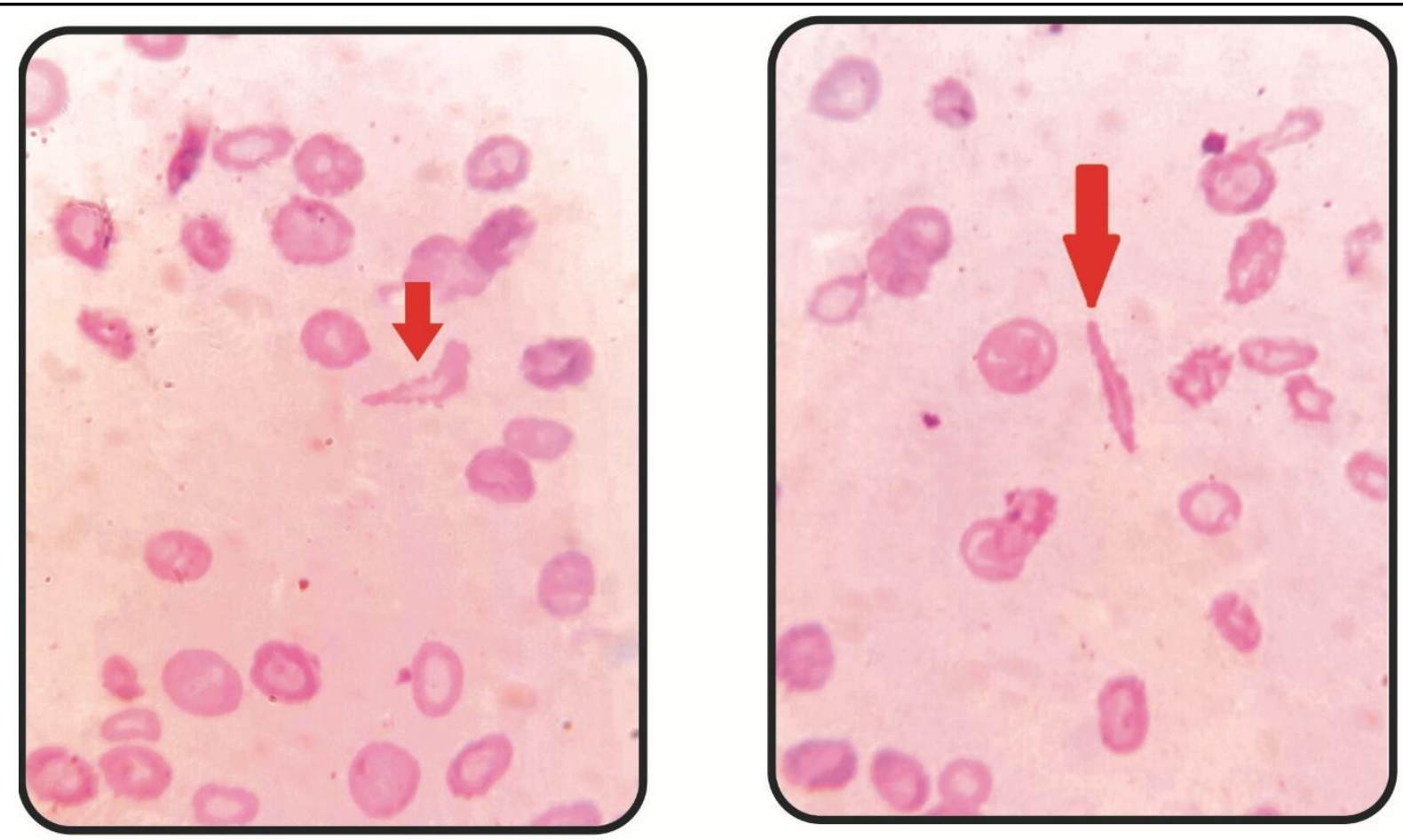

Reticulocyte Count $\mathbf{- 5 . 8 \%}$

MP / MF - Negative

Sickling Test - Positive
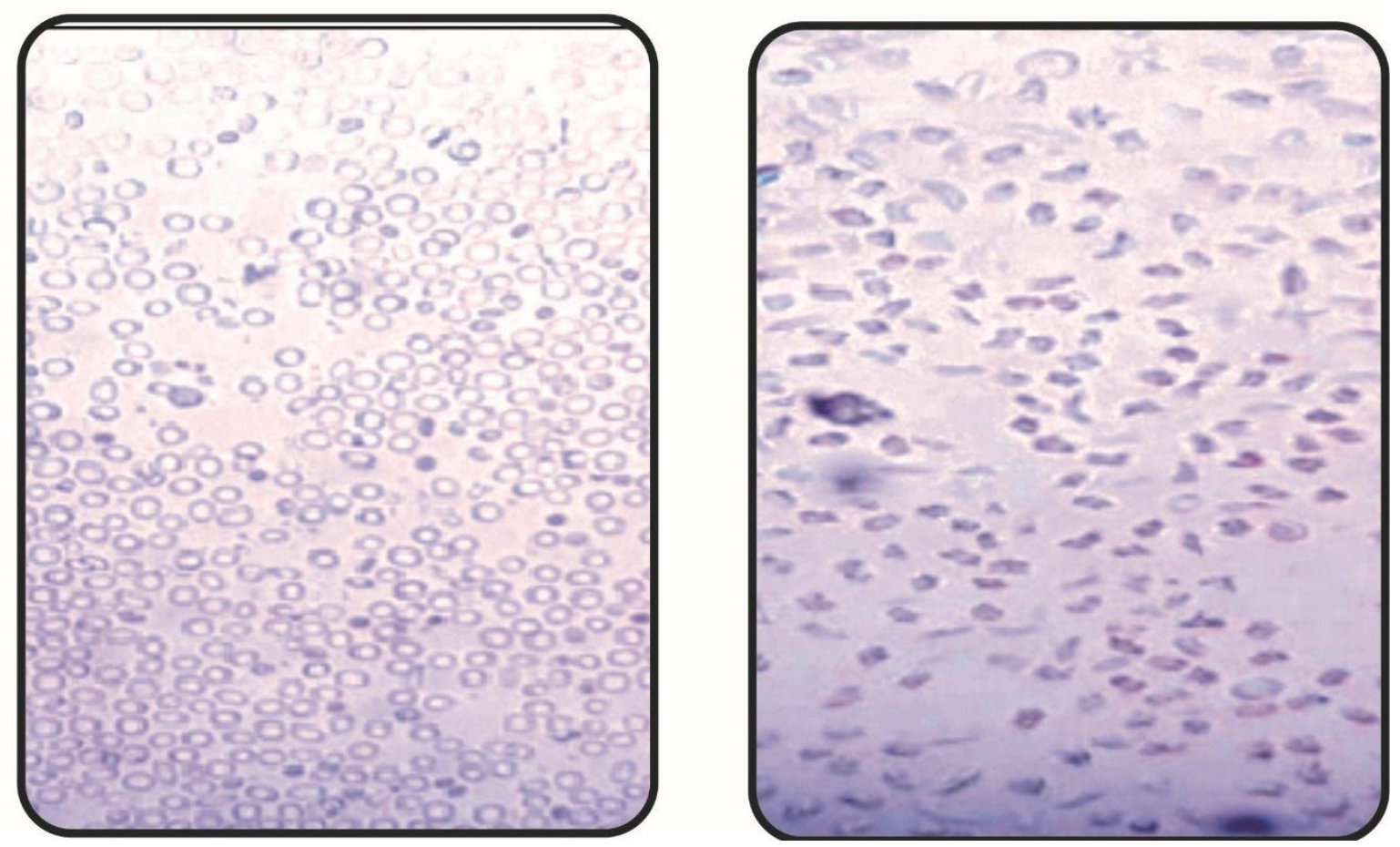

Osmotic Fragility Test- Decreased

\section{Hemoglobin Electrophoresis}

HbA1- 4\%, HbA2 -1.9\% ,HbF -24.7\%, HbS -67\% HbD -0\% 


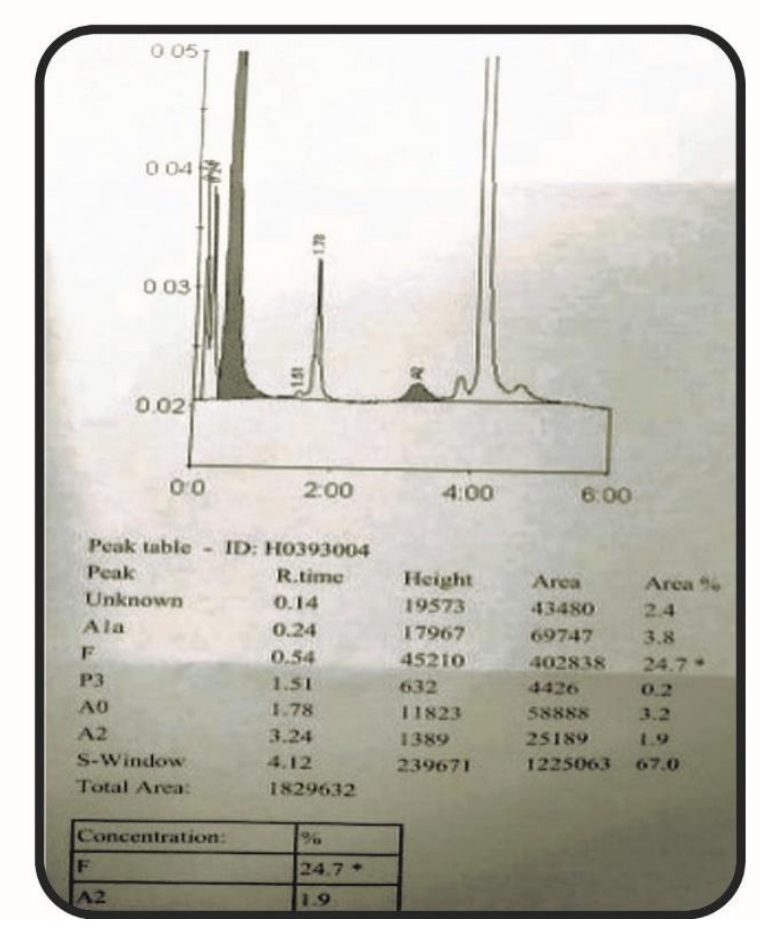

\section{Discussion}

Sickle cell anemia is the homozygous state usually manifest earlier in life. Rarely it can present in early adulthood. Though splenectomy occurs at most of the cases before 10 years of age, in patient with Sickle cell anemia (HbSS) splenomegaly may be present thereby determing the severity and frequency of vasoocclusion.The incidence of splenomegaly in Sickle cell anemia (HbSS) appears to be around $10 \%$ after 10 years of age. In our case family screening was recommended to rule out sickle cell disorders.

\section{Conclusion}

This is a case of Sickle cell anemia (HbSS) with high $\mathrm{HbF}$ which is an important etiology of persistence splenomegaly and late onset of symptoms.

\section{References}

1. The Indian Journal of Research and Reports in Medical Sciences vol 3 no3,july-sep2013

2. Journal of Ultrasound in medicine volume 35 ,issue 8,27 june 2016
3. De Gruchy Haematology 5th edition.

4. Wintrobe's Clinical Haematology 13th edition.

5. Atlas and Text book of Haematology Dr.Tejindar Singh 5th edition. 